\title{
15
}

\section{Afterword $^{1}$}

\author{
Nina Fishman
}

The idea for three international conferences examining social democracy was conceived by an informal group of British historians in the autumn of 2003. The need for an open-ended, serious examination of the past, present and future of social democracy was self-evident. Sufficient time had elapsed since the Wende to enable flexible, inquisitive historians to venture onto the old terrain of the nineteenth and twentieth centuries to test the preNovember 1989 narratives. $^{2}$ It was also an apposite moment to engage in future-gazing, a pastime in which most historians indulge, and which neuro-physiologists have discovered has a significant social utility.

There was an underlying continuity in the three conferences. They attracted scholars who were seriously interested in the subject across a gratifyingly long timeline. A substantial number of people who attended the first conference at the Institute of Historical Research in London returned as paper-givers and discussants to the second at Swansea University and then to the third at Sheffield University. There were fascinating hindsights from participants who had been young adults at the beginning of the cold war. There were also currently young adults who had never known the cold war.

It was notable that many participants had research specialisms in communism and/or conservatism/Christian democracy as well as social democracy. The resulting intellectual diversity produced exceptionally lively, wide-ranging debate both in the conference sessions and afterwards. It was, perhaps, apt that the plenary speakers for the third conference, held at Sheffield, were Richard Corbett MEP, an exemplary centre social democrat; the Cuban Ambassador; and Ed Miliband MP, now a cabinet minister in Gordon Brown's Government.

As a child of the cold war, I grew up with social democracy and had always taken its existence for granted. As a modern European historian, I had a working knowledge of social democracy's pre-1948 past. But when 
the euphoria of the 1989 springtime of nations had finally dissipated, it was clear that I needed to rethink social democracy. This afterword cannot possibly do justice to the range and depth of papers given and discussions about them which took place at the three conferences. But as a result of attending them, I am conscious of having evolved a new framework within which to place the narrative of social democracy. What follows is my own take and reflections about this intellectual pilgrimage.

\section{What's in a name?}

Like most other abstract political terms, social democracy has had neither a continuous nor a precise definition. Many anglophone historians, past and present, have only construed it literally, as describing those political parties with social democratic in their names. However, after October 1917, when the Russian Social Democratic and Labour Party was renamed as the Communist Party, a presumption of polarity between social democracy and communism prevailed, not only in political discourse but also among academics. Karl Kautsky's polemical denunciation of Leninism emphasised the democratic in social democracy in contrast to the dictatorship of the proletariat in the catechism of the Comintern's twenty-one conditions for affiliation. The Second Socialist International had been founded in 1889; the Third Communist International or Comintern was established in 1919 with the express intention of superseding the second.

A high-profile semantic conflict continued around this polarity throughout the interwar period, with communists declaring their preference for proletarian democracy as opposed to social democracy which had caved in to national jingoism in the First World War and continued to share its bed with capitalism. But in their own defence, social democrats pointed to the secession in April 1917 of Kautsky, Bernstein and others who left the Social Democratic Party (SPD) fraction in the Reichstag to form the Independent Social Democratic Party (USPD). The new party voted against war credits and opposed Germany's continuing prosecution of the war. Social democrats also highlighted the systematic way in which the infant Union of Soviet Socialist Republics was depriving trade unions of independent civil rights and citizens of political freedom. The reality of the dictatorship of the proletariat, they insisted, was a travesty of democratic socialism. ${ }^{3}$

The presumption of a polarity between communism and social democracy survived in a diluted form through the period of the united/popular front against fascism, 1935-39, returning with renewed vigour in August 1939 after the conclusion of the Ribbentrop-Molotov Pact until Hitler's invasion of the USSR in June 1941. For the rest of the Second World War, most social democrats repressed or even discarded their belief in the existence of 
an unbridgeable divide between social democracy and communism. They worked closely with communists in resistance movements in occupied Western Europe and war production campaigns in Britain, Australia and North America. Some social democrats were even willing to acknowledge that they shared a common past and ancestry with communists.

The motivation for social democrats' volte-face was complex and remains largely unexamined by contemporary scholars. Although in large part pragmatic, there was also a strong appreciation of the Soviet Union's military prowess, technological and engineering virtuosity, and economic power, e.g., the Webbs' sanguine perception of Soviet progress (Morgan 2006). The general secretary, Ernest Bevin, wrote in the Transport and General Workers' Union journal, The Record, in April 1933:

In the case of Soviet Russia, who is endeavouring to work out a different economic system from that existing in this country, we have fought determinedly against [British] intervention ... and have done everything in our power to assist her, not withstanding the fact that we have often met with abuse and attack from the Russians themselves. We have done this because we believe that this great economic experiment may considerably influence the development of world planning and social change.

The appreciation of underlying similarities continued into the peace and reconstruction. The most remarkable manifestation of this was the large number of SPD leaders and rank-and-file members who either lived in East Germany and pledged their loyalty to the Socialist Unity Party, a merger of the SPD and German communist party, or emigrated from West Germany to join it. Stalin's death in 1953 precipitated a palpable diminution of cold war tensions after which many Western European social democrats' impulse to reach out to people's democratic parties in Eastern Europe and communists in the USSR and their respective trade unions returned with heightened intensity, e.g., the persistent refusal of the British trade union movement to engage in cold war crusading, causing the American union federations, the AFL and the CIO to consider them soft on communism. In the early 1970s Willi Brandt's determined pursuit of Ostpolitik revealed the potential for more than 'peaceful co-existence'.

British cold war intellectuals and/or politicians who espoused social democracy with zealous rigour (e.g. Crosland, Gaitskell) found its essence in Kautskyist antagonism to communism and its claim to be the sole heir to the socialist tradition. Left-wing socialists frequently accepted this assertion at face value, and equated social democracy with their centreright opponents. For many Labour activists who identified with the Keep Left group of MPs and Tribune, the term social democracy was suspect because of its identification with a particular strand of socialist thought and politics. 
Another undercurrent in post-war British socialists' rejection of a social democratic identity was a self-righteous rejection of anything with demonstrably German antecedents. A British refusal to recognise common roots with things German was understandable for the generation who fought the Second World War. Its transmission to the successive three generations is remarkable. The underlying similarity between German social democracy and British labourism is undeniable. It springs from a common historical experience: on the economic front, early, intensive industrialisation and urbanisation; on the political front, the vagaries of constitutional monarchies where substantial residual power lay with a narrow elite; on the cultural front, the inheritance of the Reformation and the particular kind of conscientious individualism which it produced. Important exceptions can, of course, be found to these sweeping generalisations, e.g., in the pre-1914 empires, rural Catholic Bavarian peasants and rural Catholic Ireland. But the similarities are at least as instructive as the differences. Failure to recognise them and appreciate their significance has produced significant distortions in British politicians' and intellectuals' ability to understand the vagaries and vicissitudes of their own past.

In these respects, the Anglo-German similarity is in sharp contradistinction to France, where the first victory in the struggle for democracy was won in the decade after 1789. The emergence of le peuple and la nation, their collective political expression, as actors on the historical stage occurred before either industrialisation or extensive urbanisation. The potent force of democracy in France was unleashed not by or in the name of an urban proletariat, but rather by a wonderfully diverse collection of merchants, artisans, dissident aristocrats, shopkeepers, clerics, lawyers, and newly enfranchised wealthy peasants. By the 1850s in France, the defence of La Republique was a matter of universal concern. Countervailing forces, i.e. monarchism and ultramontane Catholicism, were ambitious but ultimately unable to reclaim the central ground of French politics. When Jules Guesde founded the French Workers' Party (POF) in 1879, he took counsel from Marx in London, explaining that 'he needed to "cut the cable that kept our workers in radical or bourgeois Jacobin waters"' (Gildea 2002: 315).

In Britain and Germany, the political elite maintained its ascendancy throughout the nineteenth century. Constitutional monarchies maintained a firm grip on the state and the political process in both spaces (in Germany this meant until 1871 the thirty-odd states remaining after Napoleonic consolidation). Intermittent manifestations of the 'the people's will' were contained with comparative ease, partly by efficient state repression but also because of the willingness of the elite to give ground under pressure, often slowly, but nonetheless tangibly. 


\section{The democracy ...}

The term 'democracy' was not inserted to proclaim the difference between social democratic parties and a non-existent communist party. In 1875 , 'Social' and 'Democratic' had equal importance for the Allgemeiner deutscher Arbeiterverein (General German Workers' Union) and the liberaldemocratic Verband deutscher Arbeitervereine (League of Workers' Clubs), the two founding groups of the Sozialdemokratische Partei Deutschlands (Social Democratic Party of Germany). 'Their anti-Prussianism was stronger than their socialism, to which, indeed their organizations did not commit themselves until 1868-9.' The Verband was based in 'Saxony, south-west Germany, and parts of Bavaria, where the Great German tradition of 1848 was still alive' (Craig 1981: 94). The SPD was a social-democratic party because it claimed not only political, but also economic rights. It is also possible that the SPD's founders, August Bebel and Wilhelm Liebknecht, like their British counterparts Keir Hardie and Will Thorn, considered it inexpedient to identify their political party too closely with an ismus. Sozialdemokratie may have been not only a more accurate descriptor than Sozialismus, but also more acceptable to contemporary political discourse.

It is equally important to remember that the goals of the men and women who founded the British Labour Party were not merely social, e.g. old age pensions, social insurance, but also democratic, e.g. proportional representation, the payment of MPs and universal suffrage. For both German and British parties, universal suffrage meant not only the enfranchisement of propertyless males, but also female suffrage. The charismatic Keir Hardie was an uncompromising champion of votes for women. Bebel's book, Die Frau und der Sozialismus, published in 1883, was reprinted fifty times before the First World War (Thorpe 2008: 30-1; Craig 1981: 210-11).

British trade union leaders, like Richard Bell and Tom Mann, welcomed the twentieth century with boundless self-confidence and were determined to wrest political control away from the narrow elite who predominated in both houses of Parliament. Bevin was clear that 'the democracy' needed political power:

The Trade Union Movement has wrenched the power from the castle and the mansion and handed it to the cottage. Gradually, as the ages rolled on, the serf class have risen in their majesty ... and they are walking more erect as citizens in this age than any previous age ... I am more proud of the movement, because out of their two-pences [to unions' political funds], you have created a royal road from cottage to Parliament so that sons of toil can express and use the very franchise which their forefathers won them, in helping to work out the salvation of the common people. (Bevin 1925) 


\section{$\ldots$ and the social}

After the First World War, when the Labour Party appeared to be a serious threat in Westminster, the Conservatives routinely referred to them as Socialists. So did the Daily Mail. Having temporarily abandoned the epithet during the wartime coalition, Churchill returned to the habit in opposition. After the Conservative defeat in July 1945, the Tory Party chairman, Lord Woolton, laid down a dictum that the Labour Party were never to be called by that name, but always referred to as the Socialists. Whether and in what way this name-calling had any impact is unclear.

The attempt to smear Labour with an ideological brush probably had little serious effect, other than confirming retired colonels' and blue rinse ladies' prejudices. It is unlikely to have influenced the outcome of elections in many marginal constituencies. There may also have been a positive effect. Being called socialist by one's opponents compelled one's thoughtful supporters to examine whether or not they were socialists, and of what socialism actually consisted. And certainly for the generation who were growing up during the 1945-51 Labour government, 'socialism' had a clear practical meaning. It was what happened during those seven years. Bevin had become Foreign Minister in that government. He is memorably shown on newsreels signing a treaty with his French counterparts in 1948, and declaring 'I am signing this treaty of friendship on behalf of Socialist Britain ...'

I can remember talking to a woman who taught secretarial studies in the higher education college where I taught shop stewards in North West London. She had grown up in Ealing in the 1940s, and was interested generally in the world, although not passionately political. It was Mrs Thatcher's second term and we were making conversation at the photocopying machine. She described herself quite unselfconsciously, 'My father was a socialist and I've always been a socialist'.

After three Rethinking Social Democracy conferences, my conclusion is that the term 'social democracy' is a reasonable linguistic approximation to the trade union and labour movement of which I feel a part. I am also prepared to accept its historical resonances. In 2008 its use as a pejorative insult by communists on the one hand and a badge of honour by centre-right cold warriors no longer seems relevant. It is difficult, for example, to distinguish the policies of the communist government of the Indian state of Kerala from the orthodox social democratic canon. Similarly, the extensive use of targets and detailed central planning in both education and the NHS by the Labour government has clear parallels with developments in the USSR and also with large capitalist corporations. 


\section{The German in social democracy}

The German SPD was the dominant party in the Second Socialist International, not only because of its size and the number of MPs in the Reichstag, but also because of the immense prestige it had gained by successfully defying Bismarck. Instead of expiring as a result of the repressive antisocialist laws passed in 1878, the SPD increased its parliamentary representation and cemented the loyalty of the newly emerging industrial proletariat. In March 1890, the new Kaiser, Wilhelm II, dismissed Bismarck and the antisocialist laws were allowed to lapse.

Not surprisingly, men and women who decided on the names of socialist parties founded after the SPD frequently decided to call themselves a Social Democratic Party in emulation of the SPD's triumph over the Iron Chancellor, for example the Belgian and Swedish socialist parties. Like the Germans, their founders were also keen to claim 'democracy' in order to stake their claim to the removal of property qualifications for parliamentary elections. Universal manhood suffrage was won in Belgium in 1913 as a result of an effective general strike, which convinced Luxemburg among others of this weapon's effectiveness in the proletariat's political armoury (Polasky 1995).

On 9 November 1918, the German SPD accepted the challenge of forming a new state, after the German General Staff had decided the war was lost and applied irresistible pressure on the Kaiser to abdicate; the SPD leader, Philipp Scheidemann, proclaimed the German Republic at a mass demonstration in front of the Reichstag. After this political revolution, Germany ceased to be a constitutional monarchy and the SPD predominated in the provisional government. Leading members of the USPD, notably Kautsky and Bernstein, came back to the SPD and played a part in the formulation of the Republic's constitution.

Contemporaries inevitably compared the German revolution with its Russian counterpart of one year previously. Their conclusion usually depended on two factors: (a) their politics; and (b) which side they had supported in the First World War. The new German republic suffered a bad press in most of the Allied countries, while the assassinations of Karl Liebknecht and Rosa Luxemburg were routinely cited as evidence of the SPD's callous attitude towards members of the working-class movement. There is no significant evidence to show that either the SPD or the constitutional structure of the Weimar Republic led directly to Hitler's coup d'etat in 1933. Social democrats' achievement in establishing a democratic republic has been rubbished by post-1933 hindsightism. While such a negative verdict was understandable during the Nazi Zeit, during the war, and in the immediate post-war period, it is no longer acceptable. A re-examination 
of the Weimar Republic is currently proceeding slowly, mainly on the cultural front (Weitz 2007). But its political legacy still awaits serious consideration by a new generation of scholars. ${ }^{4}$ The principal democratic contours of the Weimar constitution were re-enacted in the 1949 constitution of the Bundesrepublik, including the provisions for industrial democracy (Betriebsräte).

\section{Enter revisionism}

When Francis Fukuyama proclaimed the end of history in the 1990s, he was suffering from the onset of hubris, a dysfunctional condition to which triumphal victors frequently fall victim. Fukuyama sincerely believed that he had supported the winning side. With the fall of the wall the ultimate battle had been won and humankind would never again have to face another total, global conflict (Fukuyama 1992). Fukuyama evidently mistook the heady euphoria of men and women joining hands across the rubble of the Berlin Wall for an eternal condition.

Karl Marx was in much the same condition in 1848 when he wrote The Communist Manifesto. Intoxicated by the heady winds of change which blew through Europe during the springtime of nations, he confidently predicted the end of capitalism and the triumph of the workers of the world. Marx caught a serious dose of hubris, which lasted into his completion of the first volume of Kapital. By the time he began work on Volume III, he had recognised that there were too many significant countervailing forces for capitalism to be caught in the maw of its own contradictions. Nor was the industrial proletariat being progressively immiserated.

The posthumous publication of Volume III produced palpable unease and confusion in the Second International. There was no evidence that Marx still expected capitalism's imminent demise. This notable absence of revolutionary optimism called forth three responses in the socialist and trade union movement, which had been expanding throughout Europe since the 1870s. First, the fundamentalists or purists, whose lodestar continued to be a belief in the transformative qualities of revolution. They simply ignored the content of Volume III and remained focused on Volume I. Their justification for a continuing faith in the inevitability of revolution was the French Revolution from 1789-99, a living past, not even a century old when the purists, Rosa Luxemburg, Parvus and Belfort Bax, attacked the first revisionist, Eduard Bernstein.

The second response was revisionism, which attempted to deal with the changes which had taken place, both in capitalism and Marx's analysis of it. Bernstein argued that socialists' expectations of what was possible for the movement to achieve had to take account of the difference between politics 
and economics. If the bourgeois state suddenly failed or fell victim to an internal crisis (as had Louis XVI's absolute monarchy), creating the opportunity for a workers' state to arise, a socialist economy would not automatically rise out of the ashes. The economic system of capitalism would remain intact, and would have to be maintained. The process of replacing capitalism with socialism was not only a matter of politics. It would also be the result of a gradual evolution of more cooperative methods of production (Bernstein 1993).

The ideological battle between Bernstein's supporters and his revolutionary opponents was conducted with great passion at the beginning of the twentieth century, not only in Germany but also in successive Congresses of the Second International. Bernstein's principal supporters were social democrats and trade union leaders who were benefiting from the increased representation of socialists and social democrats in national parliaments (not only the Reichstag but also the Belgian and French Parliaments), and from south-west Germany, notably Baden, Hesse and Württemberg, where universal manhood suffrage and strong liberal traditions produced a more reformist political culture in state parliaments and governments. It was evident that political power could be used to modify and regulate capitalism. Although legislation could not abolish an economic system, laws which for example established a minimum wage, limited the working day, or prohibited child labour, produced significant improvements for the industrial proletariat.

A fault line inside the social democratic movement was clearly discernible by the second decade of the twentieth century, between those purists who drew inspiration from the Jacobin, revolutionary tradition of the young Marx and the pragmatists who turned to Bernstein for ideological justification. It is a division which has continued into 2008 and will surely carry on for as long as there is a socialist movement (post-war British revisionists are considered in Chapters 10 and 11 in this book). Before 1914, the division was papered over by dint of the application of large amounts of ideological glue. The glue dispensers, or emollients, constitute the third response. Their purpose is to keep the movement together, thereby rendering it capable of attracting support and winning elections. For example, August Bebel persuaded Karl Kautsky to do an intellectual hatchet job on Bernstein, even though Kautsky had told Victor Adler in personal correspondence that Bernstein was right (Tudor and Tudor 1988).

But, as Andrew Thorpe has shown in the British context, doing away with the emollients, and exposing the division between purists and revisionists has a tangible utility. Thorpe's work on the interwar British communist party highlighted the fact that its leadership made no attempt to supersede or replace the Labour Party as an alternative governing party. Instead, 
Harry Pollitt and Johnny Campbell engaged with the practical reality of British parliamentary politics and maximised the CPGB's leverage on the centrist Parliamentary Labour Party. Their influence depended not only on the USSR's growing prestige in the 1930s (in contrast to global capitalism's dismal state). They also staked a claim to be the most democratic part of the trade union movement, with their activist members operating as shop stewards and providing leadership for the 'rank-and-file' (Thorpe 1998: 2000). The CPGB was able to maximise its influence precisely because it was outside the institutional structure of British Labour, and thus immune from applications of ideological glue.

The current situation in Germany provides striking proof of Thorpe's thesis. The electoral success of the Linkspartei and the skill of its leadership have pushed not only the SPD, but also Merkel's Christian Democrats leftwards. The voting system of proportional representation and the consequent necessity for politicians to participate in coalition governments enables German trade unionists and citizens to wield more influence over their political process than in Britain, with its winner-takes-all system or Italy, where political parties at the national level were never compelled to accept a responsibility to civil society. Arguably, it is the personal ambitions of political leaders and their desire to enjoy the material spoils of government which motivates Peer Steinbrück and even Andrea Nahels to view Die Linke as the main enemy (Chapter 7 in this book provides a concise analysis of these developments). It will be fascinating to see whether in the next twenty years or so the SPD is able to adjust to having a significant party on its left. If it is unable to do so, then the Christian Democrats, as presently constituted, will swiftly step in to occupy the centre ground.

\section{Social democracy baulked?}

The majority of the conference papers focused on the post-1968 period. The analyses by Tsarouhas, Clift and Kennedy of social democratic governments' performance in Sweden, France and Spain show significant achievements and advances in expanding social provision and civil rights. Nevertheless, these practical results have been disappointing for many socialists and trade unionists. There is a palpable lack of pride in the record of social democracy. I can think of two interlinked explanations for the onset of demoralisation. First, the failure of social democratic theory to make further meaningful revisions. Although, as Pautz, Shaw and Lavelle point out, there have been many contemporary dilutions of socialism, there has been a remarkable lack of genuine revisionism. The study of Crosland in this book (Chapter 11) is highly relevant in this respect. Crosland had studied Bernstein before he began on his own revisionist exercise. He 
offered a comprehensive survey of how socialist principles might be applied to the world of the 1950s. There has been nothing comparable since.

Second, the failure of West European social democratic parties to recover from the demise of communism. It is interesting evidence of the effect of the two movements' shared parentage. During the cold war, the existence of large numbers of communist states acted as a strong bargaining card for social democratic parties and trade unions. Social democrats became accustomed to gaining concessions from employers, augmenting the welfare state and piloting through extensions of industrial democracy. They were able to argue successfully for a more equal distribution of wealth and income by citing the spectre of communism, and warning that unless concessions were made the result might be not only unrest but also revolution! The glorious events of 1968 (and Italy's hot autumn of 1969), made this Armageddon scenario all too credible to the political and economic elites.

\section{Future-gazing}

Bernstein's goal of achieving cooperative organisation in the economy and also civil society is still a valid one. However, if contemporary social democrats are going to move forward, they will have to first enquire what has changed in capitalism, and how those changes affect society. From the 1990s, it became highly fashionable to point to the prosperous present and a glowing future which beckoned for global capitalism. The economic stimulus produced by the end of the cold war in continental Europe and the seemingly limitless expansion of finance capital were apparently reinforcing each other. Meanwhile, in the USA, enterprising, ambitious people were clawing their way to the top, using the privatisations of utilities and the amazing loopholes (euphemistically described as opportunities) provided by the harnessing of computer models, e-mail, and mathematics to amass paper money fortunes which had little or no counterpart in reality.

In 2008, the many economists and journalists who had signed up to the triumphalist version of the end of the cold war have been shocked by the fact that the future of capitalism looks increasingly insecure. They had apparently concluded that, since the implosion of the USSR had proved capitalism to be a superior economic system, its indefinite expansion with resulting enrichment for deserving entrepreneurs and investors would become the New World Order. A mirror image of pro-capitalists' shock can be seen in the glee and 'I told you so' responses coming from pure socialists, who view the current vicissitudes of the global economy as being a sign that the downfall of capitalism is nigh.

The practical reality of the current economic situation is much more complex. A recently issued report from theBank of International Settlements 
concluded that the underlying causes of the credit crunch and continuing financial insecurity were the opportunities for old-fashioned greed opened up by the retreat of state financial regulation (Wolf 2008). Provided that governments and national banks find the will to reassert control over financial institutions, there is no reason to doubt the Marx of Kapital Volume III: there will be countervailing forces powering capitalism forwards and upwards into the twenty-second century. But the continuing strength of capitalism does not mean that social democracy will inevitably become weaker. Indeed, social democracy was arguably strongest at the last zenith of global capitalism, at the beginning of the twentieth century. A strong capitalism creates the conditions for a strong trade union movement and also the militant expression of democratic demands (Chapter 14 on industrial democracy in this book is very relevant to this point).

Social democracy is guaranteed a secure future as a repository of ideas, whether or not it continues to be a living political movement. Outside Europe and North America, I am optimistic about its future as a political force. Interest in social democracy is strong in the newly industrialised economies of South Korea and Taiwan. In Brazil and Argentina, social democratic ideas are influential inside the trade union movement and political parties. Increasing urbanisation and industrialisation have produced qualitative changes in the political leaderships' self-image and selfconfidence. In India, the principles and perspectives of the British labour movement, from the Marxist Social Democratic Federation through to the CPGB, permeated the Congress Party from its inception. Increasing urbanisation and industrialisation have produced qualitative changes in India, which are making the political reflexes from this pre-1948 source increasingly relevant.

The problems for social democracy in Europe are different. In Western Europe, the horizons of social democratic politicians have been so narrowed that they are only interested in two things, winning elections and managing state services. Not surprisingly, electorates have ceased to have much interest in or sense of identification with the party leaderships. An interesting exception is arguably the Spanish socialist party, the PSOE. The Spanish socialist government has recently enacted an ambitious programme of civil, democratic rights, which are discussed by Paul Kennedy in Chapter 5 in this book. Their electoral success and determination to make further progress on the democratic front is evidence that the democratic part of social democracy deserves to be taken seriously, a point also made by Martin McIvor in Chapter 13 in this book.

The problem for social democratic parties in East Central Europe is different. For the most part their leaders have been unable to show voters that social democracy is very different, either programmatically or ideologically, 
from the parties which predominated in the pre-1989 states. Many of the dominant parties in East Central Europe were not called communist parties, for example the Polish United Workers' Party - PZPR - and the East German Socialist Unity Party - SED. As I have tried to show, the assertion of an absolute difference between social democratic and communist parties is in any case inaccurate. Many of the measures enacted by communist governments were popular and genuinely improved people's standards of living. Nonetheless, determination, commitment and time will be required before social democrats in these countries can convince their citizens that there are genuine differences between the communists and social democrats.

Finally, social democrats in both Western and East Central Europe will have to engage with a twenty-first century democratic problem-how to restructure the European Union so that the Commission and the Council are directly responsible to the citizens of Europe. In chapter 9 in this book, Moschonas has rightly, in my view, flagged this task up as being vital to the future of social democracy on this continent. This process will not involve the disappearance either of nations or nation-states. The construction of a more transparent and politically accountable EU Commission and Council will not affect the validity of these historico-cultural constructs. What will change, and rightly so, is the international dimension. There will be a new historical actor, joining le Peuple and la Nation. Without an effective EU on the international stage, there can be no reasonable expectation that European citizens will be able to continue to enjoy the civil and economic advantages which social democratic governments have brought them.

There is evidence that global capitalists and political leaders of the international community have been persuaded to take the problem of climate change seriously. Governments and international organisations will be compelled to deal with the effects of climate change using many non-market means. There are many precedents in nineteenth- and twentieth century European history for constitutional monarchies and bourgeois governments adopting non-market solutions, for example Napoleon III's economic policies which drew inspiration from Saint Simon or Stanley Baldwin's determination to proceed with the electrification of Great Britain using state finances and a state holding company. It will be surprising if in the twenty-first century such expedients are not adopted again. Provided they remain self-confident and vital, social democratic parties will be able to influence the direction and structure of these new non-market solutions.

\section{Notes}

1 I am grateful to John Callaghan and Ben Jackson for reading and commenting on the first draft of this chapter. 
2 The German word Wende means turn. It was quickly adopted by Germans as their shorthand for the events leading up to the destruction of the Berlin Wall in November 1989 and its immediate aftermath. Most other Western Europeans use 'the Fall of the Wall' to describe these events. I have used Wende because it conveys a sense of motion and change, while stopping short of describing the change as revolution.

3 Marx used the expression 'dictatorship of the proletariat' in Class Struggles in France, which dealt with the events of 1848-49. Engels repeated it in his introduction to Marx's The Civil War in France, an analysis of the Paris Commune. Neither, however, probed its substance. Parties affiliated to the Second International viewed the possibility that they might participate in a dictatorship of the proletariat with equanimity. Bernstein, for example: 'So, as the first precondition of the general realisation of socialism we have a certain level of capitalist development and, as the second, we have the exercise of political power by the class party of the workers, Social Democracy. In the transitional period, the form in which this power is exercised is, according to Marx, the dictatorship of the proletariat' (Bernstein 1993: 99).

4 A relevant example of the failure to analyse the German Revolution is a conventional view which condemns the provisional government's use of the Freikorps in 1919-20 to suppress the intermittent upsurges of resistance from workers' councils and/or urban unrest. The conclusion is that because the government allowed the Freikorps to deploy, they could no longer be considered social democratic, republican or revolutionary. However, if the suppression of workers' councils is to be used as a litmus test, then Lenin, Trotsky and the other Bolsheviks who participated in the brutal suppression of the Kronstadt Rebellion in February-March 1921 should also stand condemned. Although most historians today recognise the Bolsheviks' suppression of Kronstadt, they continue to regard the post-Kronstadt Bolshevik leadership as being sincere communists who were trying to construct socialism.

\section{References}

Bernstein, E. (1993) The Preconditions of Socialism, 1899, ed. and trans. H. Tudor (Cambridge: Cambridge University Press).

Bevin, E., speech in Yarmouth Town Hall on 23 March 1925, quoted in The Record, journal of the Transport and General Workers' Union, May 1925.

Craig, G. A. (1981) Germany 1866-1945 (Oxford: Oxford University Press).

Fukuyama, F. (1992) The End of History and the Last Man (New York: The Free Press).

Gildea, R. (2002) Barricades and Borders, Europe 1800-1914, 3rd edn (Oxford: Oxford University Press).

Morgan, K. (2006) The Webbs and Soviet Communism, Bolshevism and the British Left Part 2 (London: Lawrence \& Wishart).

Polasky, J. (1995) The Democratic Socialism of Emile Vandervelde Between Reform and Revolution (Oxford: Berg), Chapter 2. 
Thorpe, A. (1998) 'Comintern "control” of the Communist Party of Great Britain, 1920-1943', English Historical Review, 113.

Thorpe, A. (2008) A History of the British Labour Party, 3rd edn (Basingstoke: Palgrave).

Tudor, H. and Tudor, J. M. (eds) (1988) Marxism and Social Democracy: the Revisionist Debate 1896-98 (Cambridge: Cambridge University Press).

Weitz, E. D. (2007) Weimar Germany: Promise and Tragedy (Princeton: Princeton University Press).

Wolf, M. (2008) 'The lessons to be learnt from today's financial crisis', Financial Times, 2 July, discussing Annual Report of Bank for International Settlements. 